\title{
ASI eksklusif berhubungan dengan perkembangan bayi di Kecamatan Gading Cempaka Kota Bengkulu
}

\author{
Kamsiah ${ }^{1}$, Detty Siti Nurdiati², Emy Huriyati ${ }^{3}$
}

\begin{abstract}
Background: Malnutrition is a major problem in Indonesia nowadays. Malnutrition will affect the quality of human resources in the future. Age of 7-12 months is a critical and golden period for the process of child development. Early complementary breastfeeding is one of causes the prevalence child development disorder.

Objective: To find out the relationship between exclusive breastfeeding and the development of infants 7-12 months old at the Health Center at Jalan Gedang, Sub District of Gading Cempaka, Bengkulu Municipality.

Method: This observational study used cross sectional design. There were as many as 75 samples of infants 7-12 months old taken using cluster random sampling. Data of breastfeeding were obtained from questionnaires, data of development were obtained from questionnaires with pre-screening development format. Data analysis used chi square and logistic regression statistical test.

Result: There was significant relationship between exclusive breastfeeding and infant development $(p<0.05)$. There was significant relationship between birth weight and infant development $(p<0.05)$. There was no significant relationship between method of childbirth, education of mothers, mothers'occupation, family income and infant development ( $p>0.05)$. The result of multivariable analysis showed that birth weight was a predictor of infant development $(O R=5.231)$.

Conclusion: There was significant relationship between exclusive breastfeeding and the development of infants of 7-12 months old. Birth weight was a dominant factor related to the development of infants of 7-12 months old.
\end{abstract}

KEYWORDS:exclusive breastfeeding, infant development

\begin{abstract}
ABSTRAK
Latar belakang: Malnutrisi menjadi masalah utama di Indonesia yang akan berpengaruh terhadap kualitas sumber daya manusia pada masa yang akan dating. Usia 7-12 tahun merupakan masa kritis dan masa keemasan bagi perkembangan anak. Pemberian MPASI (makanan pendamping ASI) yang terlalu dini merupakan salah satu penyebab gangguan perkembangan bayi.

Tujuan: Untuk mengetahui hubungan antara ASI eksklusif dengan perkembangan bayi di Puskesmas Jalan Gedang Kecamatan Gading Cempaka Kota Bengkulu.

Metode: Jenis penelitian ini adalah observasional menggunakan rancangan cross sectional. Jumlah sampel adalah 75 bayi berusia 7-12 bulan yang dipilih menggunakan simple random sampling.Data diperoleh melalui kuesioner dan wawancara, kemudian dianalisis menggunakan uji Chi Square dan regresi logistik dengan confidence interval (Cl) $95 \%$.

Hasil: Ada hubungan bermakna antara ASI eksklusif dengan perkembangan bayi dan antara berat badan lahir dan perkembangan bayi $(p<05)$, namun tidak ditemukan hubungan antara metode persalingan, pendidikan ibu, pekerjaan ibu, dan pendapatan keluarga dengan perkembangan bayi $(p>0,05)$. Hasil analisis multivariat menunjukkan bahwa berat badan lahir merupakan prediktor perkembangan bayi $(O R=5,231)$.

Kesimpulan: Ada hubungan bermakna antara ASI eksklusif dengan perkembangan bayi 7-12 bulan. Berat badan lahir merupakan faktor dominan yang berhubungan dengan perkembangan bayi 7-12 bulan.
\end{abstract}

KATA KUNCI: ASI eksklusif, perkembangan bayi

\section{PENDAHULUAN}

Angka kematian bayi (AKB) di Indonesia masih cukup tinggi. Menurut data Survei Demografi Kesehatan Indonesia (SDKI) tahun 2003, AKB menunjukkan angka 20 per 1.000 kelahiran hidup (1). Salah satu upaya untuk menurunkan AKB adalah dengan memperhatikan gizi melalui pemberian air susu ibu (ASI) secara eksklusif (2), yaitu memberikan ASI saja tanpa makanan tambahan lain hingga bayi berusia 6 bulan (3).

Komposisi ASI mengandung zat-zat gizi berkualitas tinggi yang sangat berguna untuk pertumbuhan dan perkembangan bayi/anak. Anggapan bahwa susu kaleng cair maupun bubuk pada iklan di media sama baiknya dengan ASI tidak dapat dibenarkan (4), bahkan mutu susu yang dimanusiawikan (humanized milk) tidak akan sebaik susu ibu. Oleh karena itu, bayi yang diberi ASI akan

\footnotetext{
${ }^{1}$ Poltekkes Kemenkes Bengkulu Jurusan Gizi, Jl. Indragiri No. 3 Padang Harapan, Bengkulu

${ }^{2}$ RSUP Dr.Sardjito Bagian Obstetridan Ginekologi, JI. Kesehatan 1 Yogyakarta

${ }^{3}$ Prodi Gizi Kesehatan Fakultas Kedokteran Universitas Gadjah Mada, Jl. Farmako, Sekip Utara, Yogyakarta 55281, e-mail:emy_huriyati@ yahoo.com
} 
mempunyai tingkat kecerdasan (IQ) yang sempurna, yang merupakan sumber daya manusia (SDM) yang sangat berkualitas (5).

Pencapaian ASI eksklusif di Bengkulu hanya 39,5\%, sedangkan target nasional adalah $80 \%$. Selain itu, masih banyak ditemukan anak dengan perkembangan yang tidak sesuai dengan usianya (6). WHO merekomendasikan bahwa semua bayi harus mendapatkan ASI eksklusif sampai usia 6 bulan dan menyusui secara eksklusif akan menciptakan faktor lingkungan yang optimal untuk meningkatkan kecerdasan bayi (3).

Otak balita lebih plastis yang memiliki sisi positif, yaitu lebih terbuka untuk proses pembelajaran dan pengkayaan, sedang sisi negatif yaitu lebih peka terhadap lingkungan yang tidak mendukung, seperti asupan gizi yang tidak adekuat, kurang stimulasi, dan tidak mendapatkan pelayanan kesehatan yang memadai. Masa lima tahun pertama kehidupan merupakan masa yang sangat peka terhadap lingkungan dan masa ini berlangsung sangat pendek serta tidak dapat diulang lagi. Masa balita tersebut sebagai "masa keemasan" (golden period)," jendela kesempatan" (window of oppurtunity), dan "masa kritis" (5).

Pemantauan perkembangan anak secara komprehensif dan berkualitas penting diselenggarakan melalui kegiatan stimulasi, deteksi, dan intervensi dini penyimpangan tumbuh kembang anak dilakukan pada "masa kritis". Sehingga dapat menghasilkan SDM yang berkualitas (2). Gangguan pertumbuhan dan perkembangan yang terjadi pada awal kehidupan balita merupakan salah satu akibat dari pemberian makanan pendamping ASI (MPASI) yang terlalu dini dan ketidakberhasilan ibu dalam memberi ASI eksklusif kepada bayinya (7). Penelitian ini bertujuan untuk mengetahui hubungan ASI eksklusif dengan perkembangan bayi di Puskesmas Jalan Gedang Kota Bengkulu.

\section{BAHAN DAN METODE}

Jenis penelitian ini adalah survei analitik dengan rancangan cross sectional yang dilakukan di wilayah kerja Puskesmas Jalan Gedang Kota Bengkulu pada bulan Agustus sampai dengan Oktober 2007.Subjek pada penelitian ini adalah bayi yang berumur 7-12 bulan dengan kriteria inklusi menyusu pada ibu. Adapun kriteria eksklusi adalah bayi yang bukan anak adopsi, sedang tidak menderita sakit, dan tidak menderita kelainan atau penyakit bawaan. Jumlah sampel pada penelitian ini adalah 75 bayi, yang diambil dengan caracluster sampling. Data diperoleh melalui kuesioner dan wawancara terhadap responden (ibu bayi).

Variabel penelitian terdiri dari variabel bebas yaitu pemberian ASI pada bayi, sedangkan variabel terikat adalah perkembangan bayi. Variabel terkendali adalah metode persalinan, berat badan lahir, pekerjaan ibu, pendidikan ibu, dan pendapatan keluarga.

Pengolahan data menggunakan komputer, melalui 4 tahapan yaitu editing, coding, processing dan cleaning. Untuk mengetahui hubungan antara variabel bebas dengan variabel terikat dilakukan dengan uji Chi Square, sedangkan untuk mengetahui faktor dominan yang paling berpengaruh terhadap perkembangan bayi digunakan regresi logistik. Batas kemaknaan untuk semua uji statistik adalah $\mathrm{p}<0,05$.

\section{HASIL DAN BAHASAN}

\section{Karakteristik responden}

Karakteristik responden pada penelitian ini dapat dilihat pada Tabel 1.

Berdasarkan Tabel 1, dapat dilihat sebagian besar bayi mendapatkan ASI eksklusif $58,7 \%$ dan yang dilahirkan secara spontan sebanyak $86,7 \%$. Sebagian

Tabel 1. Distribusi karakteristik responden di Wilayah Puskesmas Jalan Gedang Kecamatan Gading Cempaka Kota Bengkulu tahun 2007

\begin{tabular}{|c|c|c|}
\hline Karakteristik & $\begin{array}{c}\text { Frekuensi } \\
\text { (f) }\end{array}$ & $\begin{array}{c}\text { Persentase } \\
(\%)\end{array}$ \\
\hline \multicolumn{3}{|l|}{ Pemberian ASI } \\
\hline Eksklusif & 44 & 58,7 \\
\hline Tidak eksklusif & 31 & 41,3 \\
\hline Jumlah & 75 & 100 \\
\hline \multicolumn{3}{|l|}{ Metode persalinan } \\
\hline Spontan & 65 & 86,7 \\
\hline Tindakan & 10 & 13,3 \\
\hline Jumlah & 75 & 100 \\
\hline \multicolumn{3}{|l|}{ Berat badan lahir } \\
\hline Normal & 62 & 82,7 \\
\hline Tidak normal & 13 & 17,3 \\
\hline Jumlah & 75 & 100 \\
\hline \multicolumn{3}{|l|}{ Pendidikan ibu } \\
\hline Tinggi ( $>12$ tahun) & 30 & 40 \\
\hline Menengah (>9-12 tahun) & 34 & 45,3 \\
\hline Rendah (0-9 tahun) & 11 & 14,7 \\
\hline Jumlah & 75 & 100 \\
\hline \multicolumn{3}{|l|}{ Pendapatan keluarga } \\
\hline Tinggi ( $\geq \operatorname{Rp} 1.637 .531)$ & 22 & 29,3 \\
\hline Rendah (SRp 1.637.531) & 53 & 70,7 \\
\hline Jumlah & 75 & 100 \\
\hline \multicolumn{3}{|l|}{ Perkembangan bayi } \\
\hline Sesuai usia & 43 & 57,3 \\
\hline Tidak sesuai usia & 32 & 42,7 \\
\hline Jumlah & 75 & 100 \\
\hline
\end{tabular}

besar bayi dilahirkan dengan berat badan lahir normal sebanyak $82,7 \%$, sedangkan pendidikan subjek penelitian terbanyak pada tingkat pendidikan menengah $(45,3 \%)$ dan tingkat pendidikan rendah terdapat $14,7 \%$. Dilihat dari segi pendapatan, terdapat $70,7 \%$ responden mempunyai penghasilan rendah dan dilihat dari segi perkembangan 
bayi, sebagian besar mempunyai perkembangan yang sesuai dengan usianya $(57,3 \%)$.

\section{Hubungan antarvariabel}

Hubungan antara pemberian ASI, metode persalinan, berat badan lahir, pendidikan ibu, dan pekerjaan ibu dengan perkembangan bayi dapat dilihat Tabel 2. Dari segala sudut pertimbangan, ASI merupakan makanan terbaik bagi bayi karena mengandung nutrien yang cukup tinggi yang banyak memberi manfaat terutama untuk pertumbuhan dan perkembangan anak, sehingga mencapai SDM yang berkualitas di kemudian hari (8). Pada penelitian ini, didapatkan hasil $68,2 \%$ dari 44 bayi yang diberikan ASI eksklusif mengalami perkembangan yang sesuai, sedangkan bayi yang tidak diberikan ASI eksklusif namun mengalami perkembangan yang sesuai jumlahnya lebih kecil yaitu $41,9 \%$ dari 31 bayi. Hasil uji statistik diperoleh $p=0,043$ yang berarti terdapat hubungan yang bermakna antara pemberian ASI eksklusif dengan perkembangan bayi, dengan $\mathrm{OR}=2,967$ (95\%Cl: 1,142-7,708) yang berarti bayi yang diberikan ASI eksklusif mempunyai peluang 2,967 kali untuk mempunyai perkembangan yang sesuai dibandingkan bayi yang tidak diberikan ASI eksklusif.

Hasil penelitian ini sejalan dengan penelitian yang dilakukan Escamilla (9) yang menunjukkan bahwa ASI dapat mempengaruhi perkembangan anak secara statistik (95\% Cl: 4,51-6,14), yaitu mengandung zat kimia bioaktif yang berperan penting untuk perkembangan otak. Hal tersebut juga sejalan dengan penelitian yang dilakukan oleh Andarwati et al. (10) di kecamatan Prambanan Kabupaten Sleman yang menunjukkan bahwa ASI eksklusif berhubungan dengan kecerdasan anak.Hasil penelitian Stephen et al. (11) juga menyimpulkan adanya hubungan yang bermakna antara pemberian ASI dengan kemunduran perkembangan anak dengan keterangan anak yang menyusu kurang dari 6 bulan berisiko terjadinya gangguan perkembangan. Hasil penelitian Anderson et al. (12) juga mendapatkan hasil bahwa ada hubungan ASI eksklusif dengan status gizi anak. Hasil penelitian ini jelas membuktikan bahwa ASI sangat mendukung perkembangan otak bayi secara optimal karena zat yang terdapat dalam ASI tidak ada yang dapat menyamai dengan susu lain (13).

Adanya komplikasi persalinan pada bayi seperti trauma kepala yang biasa dialami pada bayi yang lahir dengan pertolongan tindakan dapat menyebabkan kerusakan jaringan otak (14). Pada penelitian ini, didapatkan hasil bahwa $60 \%$ dari 65 orang bayi yang dilahirkan secara secara spontan mengalami perkembangan yang sesuai, sedangkan $40 \%$ dari 10 orang bayi yang dilahirkan dengan tindakan mengalami perkembangan yang sesuai. Dari uji statistik juga didapatkan tidak ada hubungan yang bermakna antara metode persalinan dengan perkembangan bayi.

Nutrisi pada ibu hamil akan berpengaruh pada pertumbuhan janin yang akan dilahirkan (2). Bayi berat lahir rendah (BBLR) dipengaruhi oleh beberapa faktor, seperti: umur ibu, paritas, status gizi (nutrisi) pada waktu hamil (15). Pada penelitian ini, didapatkan hasil OR=6,06 (95\% Cl: 1,508-24,360) yang berarti bayi dengan berat badan lahir normal mempunyai peluang 6,06 kali untuk mempunyai perkembangan yang sesuai dibandingkan

Tabel 2. Hubungan pemberian ASI, metode persalinan, berat badan lahir, pendidikan ibu, dan pekerjaan ibu dengan perkembangan bayi

\begin{tabular}{|c|c|c|c|c|c|}
\hline \multirow{2}{*}{ Variabel } & \multicolumn{2}{|c|}{ Perkembangan bayi } & \multirow{2}{*}{ Total } & \multirow{2}{*}{ OR } & \multirow{2}{*}{$95 \% \mathrm{Cl}$} \\
\hline & Sesuai & Tidak & & & \\
\hline \multicolumn{6}{|l|}{ Pemberian ASI } \\
\hline Eksklusif & 30 & 14 & 44 & 1,000 & $1,142-7,708$ \\
\hline Tidak eksklusif & 13 & 18 & 31 & 2,967 & \\
\hline \multicolumn{6}{|l|}{ Metode persalinan } \\
\hline Spontan & 39 & 26 & 65 & 1,000 & $0,587-8,758$ \\
\hline Tindakan & $4^{*}$ & 6 & 10 & 2,250 & \\
\hline \multicolumn{6}{|l|}{ Berat badan lahir } \\
\hline Normal & 40 & 22 & 62 & 1,000 & $1,508-24,360$ \\
\hline Tidak normal & $3^{*}$ & 10 & 13 & 6,061 & \\
\hline \multicolumn{6}{|l|}{ Pendidikan ibu } \\
\hline Tinggi & 16 & 14 & 30 & 1,000 & $0,228-1,702$ \\
\hline Menengah & 22 & 12 & 34 & 0,623 & $0,343-5,488$ \\
\hline Rendah & 5 & 6 & 11 & 1,371 & \\
\hline \multicolumn{6}{|l|}{ Pekerjaan ibu } \\
\hline Tidak bekerja & 32 & 24 & 56 & 1,000 & $0,338-2,780$ \\
\hline Bekerja & 11 & 8 & 19 & 0,970 & \\
\hline \multicolumn{6}{|l|}{ Pendapatan keluarga } \\
\hline Tinggi & 15 & 7 & 22 & 1,000 & $0,672-5,450$ \\
\hline Rendah & 28 & 25 & 53 & 0,333 & \\
\hline
\end{tabular}

*sel yang nilainya kurang dari lima 
bayi dengan berat badan lahir tidak normal. Penelitian yang dilakukan pada bayi BBLR didapatkan hasil bahwa anak yang lahir dengan BBLR mempunyai risiko 3,34 kali lebih besar untuk mengalami status gizi kurang dibandingkan dengan anak yang tidak $\operatorname{BBLR}(15,16)$. Status gizi yang kurang akan sangat mempengaruhi pertumbuhan anak dan perkembangan akan berkorelasi dengan pertumbuhan. Saat pertumbuhan berlangsung cepat, perkembanganpun demikian. Anak yang sehat akan bertambah berat badan dan tinggi badannya serta bertambah kepandaiannya (17).

Pendidikan ibu merupakan salah satu faktor pendukung perkembangan anak $(2,5)$. Seorang ibu yang berpendidikan tinggi akan mengetahui lebih banyak tentang perawatan dan pengasuhan anaknya (18). Penelitian ini menunjukkan bahwa $53,3 \%$ dari 30 bayi dengan pendidikan ibu tinggi mengalami perkembangan yang sesuai, $64,7 \%$ dari 34 bayi dengan pendidikan ibu menengah, mengalami perkembangan yang sesuai, dan $45,5 \%$ dari 11 bayi dengan pendidikan ibu rendah mengalami perkembangan yang sesuai. Dari uji statistik didapatkan nilai $p=0,452$ yang berarti tidak terdapat hubungan yang bermakna antara pendidikan ibu dengan perkembangan bayi.

Tingkat pendidikan tidak selalu berbanding lurus dengan pengetahuan.lbu dengan tingkat pendidikan rendah bisa memiliki pengetahuan yang lebih baik dari ibu dengan tingkat pendidikan tinggi (19). Hal ini dapat disebabkan telah banyaknya media informasi yang dapat diakses dengan mudah oleh masyarakat, seperti: televisi, radio, majalah, dan lain-lain, sehingga tanpa pendidikan formal pun seorang ibu bisa memiliki pengetahuan yang memadai untuk mengoptimalkan tumbuh kembang anaknya (20). Hasil penelitian Dauls et al.(16) yang menemukan tidak terdapat hubungan yang bermakna antara tingkat pendidikan ibu dengan perkembangan mental psikomotor.Demikian pula penelitian Ithorsdottir et al. (13) yang menemukan tidak terdapat hubungan yang bermakna antara tingkat pendidikan ibu dengan perkembangan anak balita.Pada era modernisasi sekarang ini, seorang ibu tidak hanya semata-mata melakukan pekerjaan rumah tangga melainkan harus bekerja untuk membantu mendapatkan penghasilan guna memenuhi kebutuhan keluarga.

Ditinjau dari sisi bekerja/tidaknya ibu, 57,1\% dari 56 bayi dengan ibu yang tidak bekerja mengalami perkembangan yang sesuai dan $57,9 \%$ dari 19 bayi dengan ibu yang bekerja, mengalami perkembangan yang sesuai. Hasil uji statistik didapatkan nilai $p=1,000$ yang berarti tidak terdapat hubungan yang bermakna antara pekerjaan ibu dengan perkembangan bayi $(p>0,05)$. Penelitian Antoni et al. (21) menyatakan ada pengaruh pekerjaan ibu terhadap status kesehatan anak, yaitu ibu-ibu yang bekerja status kehadiran orang tua dalam keluarga berkurang (16). Kecenderungan memiliki waktu yang sedikit akibat sibuk bekerja memungkinkan ibu tidak optimal dalam memperhatikan perkembangan anaknya, setelah pulang ke rumah akibat ibu yang sudah kelelahan dalam bekerja. Walaupun pekerjaan akan mempengaruhi waktu kebersamaan ibu terhadap anaknya, yang terpenting adalah kualitas interaksi ibu dan anak yang sangat penting. Hal ini juga perkembangan anak, bukan semata disebabkan pekerjaan seorang ibu akan tetapi dipengaruhi juga oleh keterlibatan anggota keluarga yang lain selain ibu, misalnya yang mengasuh anak dan lain-lain (5).

Pendapatan keluarga yang memadai akan menunjang tumbuh kembang seorang anak, karena orang tua dapat menyediakan semua kebutuhan anak baik yang primer maupun sekunder (2). Pada penelitian ini, $68,2 \%$ dari 22 bayi dengan pendapatan keluarga tinggi mengalami perkembangan yang sesuai dan $52,8 \%$ dari 53 bayi dengan pendapatan keluarga rendah mengalami perkembangan yang sesuai. Dari uji statistik didapatkan nilai $p=0,333$ yang berarti tidak terdapat hubungan yang bermakna antara pendapatan keluarga dengan perkembangan bayi $(p>0,05)$.

Penelitian ini sejalan dengan penelitian yang dilakukan Nugroho et al. (22) yang menyatakan bahwa kondisi sosial ekonomi keluarga bukan merupakan variabel yang berhubungan dengan perkembangan anak di instalasi maternal perinatal (IMP) RS. Dr. Sarjito Yogyakarta.

\section{Variabel yang paling berhubungan}

Untuk mengetahui variabel yang berhubungan dengan perkembangan bayi dapat dilihat pada Tabel 3 .

Tabel 3. Analisis regresi logistik antara variabel prediksi terhadap perkembangan bayi

\begin{tabular}{lcc}
\hline \multicolumn{1}{c}{ Variabel } & OR & $\mathbf{9 5 \% ~ C l}$ \\
\hline Pemberian ASI & 2,569 & $0,947-6,969$ \\
Berat badan lahir & 5,231 & $1,262-21,685$ \\
\hline Constant & \multicolumn{2}{c}{$-0,975$} \\
\hline
\end{tabular}

Berdasarkan Tabel 3 diketahui bahwa variabel yang berhubungan dengan perkembangan bayi adalah berat badan lahir dengan nilai OR 5,231 (95\% Cl: 1,262$21,685)$, yang berarti bahwa bayi yang dilahirkan dengan berat badan normal mempunyai peluang 5,231 kali untuk mempunyai perkembangan sesuai usia dibandingkan bayi dengan berat badan lahir tidak normal setelah dikontrol variabel pemberian ASI eksklusif.

Berat badan lahir rendah merupakan prediktor yang dapat menghambat perkembangan anak. Anak yang lahir dengan berat badan rendah akan menghambat pertumbuhan fisik anak. Perkembangan berlangsung seiring dengan pertumbuhan, misalnya anak yang sehat yang bertambah berat dan tinggi badannya, maka kepandaiannya pun akan bertambah $(2,5)$. 


\section{KESIMPULAN}

Berdasarkan pembahasan di atas, dapat disimpulkan adanya hubungan yang bermakna antara pemberian ASI eksklusif dengan perkembangan bayi usia 7-12 bulan. Variabel berat badan lahir merupakan faktor dominan yang berhubungan dengan perkembangan bayi umur 7-12 bulan

Oleh karena itu, disarankan untuk diadakannya peningkatan penyuluhan dan pendidikan gizi yang berkaitan dengan peningkatan pemberian ASI eksklusif pada bayi sampai berusia 6 bulan. Penelitian lanjutan dengan rancangan penelitian yang berbeda juga diperlukan guna mengetahui berbagai faktor lain yang berpengaruh terhadap perkembangan bayi umur 7-12 bulan.

\section{RUJUKAN}

1. Departemen Kesehatan RI. Jaringan informasi pangan dan gizi. Jakarta: Breastfeeding Good For Babies, Mother and The Planet 2001;19 (1):1-8.

2. Soetjiningsih. ASI. Jakarta: EGC; 1997.

3. WHO. The optimal duration of breastfeeding. Geneva: WHO; 2001.

4. Sediaoetama AD. IImu Gizi. Jakarta: Dian Rakyat; 2004.

5. Departemen Kesehatan RI. Pedoman pelaksanaan stimulasi, deteksi dan intervensi dini tumbuh kembang anak di tingkat pelayanan dasar. Jakarta: Depkes RI; 2005.

6. Dinas Kesehatan Kota Bengkulu. Profil kesehatan Kota Bengkulu. Bengkulu: Dinas Kesehatan Kota Bengkulu; 2006.

7. Amiruddin R. Tumbuh kembang anak [Internet] [diakses 6 Desember 2007]. Tersedia dalam: http// www.Gizi.net.

8. Wiryo H. Peningkatan gizi bayi, anak, ibu hamil dan menyusui dengan bahan makanan lokal. Jakarta: Sagung Seto; 2002.

9. Escamilla PR. Influence of breastfeeding on psychososial development. Enclopedia On Early Childhood Development 2005;18(04).
10. Andarwati R, Prawirohartono EP, Gamayanti IL. Hubungan berat bayi lahir, pemberian ASI eksklusif, status gizi dan stimulasi kognitif dengan kecerdasan anak usia 5-6 tahun. Jurnal Gizi Klinik Indonesia 2006;101-7.

11. Stephen TS, Hillary SK, Cohen, Debora L, Akshoomat NA, Macera CA, et al. Breastfeeding, infant formula supplementation and autistic disorder. International Breastfeeding Journal 2006;16 (1).

12. Anderson JW, Johnson BM, Remley DT. Breastfeeding and cognitif development. Am J Clin Nutr 1999;525-35.

13. Ithorsdottir, Igunnarstdottir, Makvaran, Gratersson SJ. Maternal body mass index, duration of exclusive breastfeeding and children's development status at the age of 6 years. Eur J Of Clin Nutr 2005; 59:426-32.

14. Dewey KG, Cohen RJ, Brown KH, Rivera LL. Effect of exclusive breastfeeding for four versus six months on maternal nutritional and infant motor development. J Nutr 2001; 131:262-7.

15. Der G, Batty GD, Deary IJ. Effect breastfeeding on intelegence in children. BMJ 2006: 38978-699583.

16. Dauls MC, Adair LS. Breastfeeding influences cognitive development in Filipino children. J Nutr 2005;135:258995.

17. Hurlock EB. Perkembangan anak. $6^{\text {th }}$ Edition (Alih Bahasa: Tjandrasa M).Jakarta: Erlangga;1978.

18. Sacharin RM. Prinsip keperawatan pediatrik. Edisi 2. (Alih Bahasa: Maulany RF).Jakarta: EGC; 1996.

19. Departemen Kesehatan RI. Buku panduan manajemen laktasi. Jakarta: Depkes RI; 2001.

20. Bobak IM, Lowdermilk DL, Jensen MD, Perry SE. Keperawatan maternitas. Edisi 4. (Alih Bahasa: Wijayarani M) Jakarta: EGC; 2000.

21. Antoni H, Castro T, Pramastri I. Hubungan pola MP-ASI dengan tumbuh kembang gerak mottorik kasar bayi 6-12 bulan di Kecamatan Bermani Ulu Kabupaten Rejang Lebong. Jurnal Gizi Klinik Indonesia 2005;60-7.

22. Nugroho AWP, Ismail D, Surjono A. Pengaruh hiperbilirubinemia pada neunatus cukup bulan terhadap perkembangan anak usia 3-5 tahun. Sains Kesehatan 2001:1-10. 